\title{
Joyce, IL BEL PAESE ANd The ItAlian LANGUAGe
}

\author{
JOHN MCCOURT
}

The first striking consideration necessary for any appraisal of Joyce's deep and ongoing relationship with Italy and with the Italian language is that it originated in his own personal and rather unusual choice to study Italian at school. He opted for Italian when he was a young pupil at Belvedere College at a time when few students selected Italian as an option either in school or at university. Joyce draws attention to the singularity of this choice in Stephen Hero making Stephen the only student of Italian at University College Dublin - when he himself had in fact been one of a select few:

He chose Italian as his optional subject, partly from a desire to read Dante seriously, and partly to escape the crush of French and German lectures. No-one else in the college studied Italian and every second morning he came to the college at ten o'clock and went up to Father Artifoni's bedroom (SH 152)

Joyce's relationship with Italian - "the Cinderella of modern languages" (JJII 46) - was not accidental, occasional or dependent on the fact that fate saw him establish himself as an exile and an English language teacher in the Austro-Hungarian port of Trieste, a city where Italian or better the local dialect of Triestino was predominantly spoken. Triestino was de facto the lingua franca of Trieste's multilingual, ethnically mixed population.

Too often still today, the important influence Italy exercised over Joyce is underestimated although an appreciation of Joyce as, among other things, an "Italian" writer is more widely acknowledged. Understanding Joyce's immersion in Italian language and literature is an essential element to be considered if we are to reach any comprehensive understanding of Joyce as a European Irish writer.

The long reticence about fully accepting the importance of Italy, Italian culture, music, literature and language may partly have been caused by Joyce's own rather caustic and unflattering comments about Italy and Italian cities. He referred to Pola - a Venetian coastal town 
that was still part of the Austro-Hungarian empire when he lived there in late 1904 and early 1905 as a "naval Siberia" while Ancona, which he passed through, en route to Rome from Trieste, was dismissed as a "Filthy hole: like rotten cabbage" (Letters II 114). Worse insult awaited Rome, which he branded "the stupidest old whore of a town ever I was in" (Letters II 198). Although Joyce often complained about his "long drudgery and disappointment in Trieste" (Letters I $215)$, it was the one "Italian" city about which he would write affectionately, for instance in a 1909 letter to Nora from Dublin:

Oh how I shall enjoy the journey back! Every station will be bringing me nearer to my soul's peace. O how I shall feel when I see the castle of Miramar among the trees and the long yellow quays of Trieste! Why is it I am destined to look so many times in my life with my eyes of longing on Trieste? (SL 193).

And again, shortly afterwards:

La nostra bella Trieste! I have often said that angrily but tonight I feel it true. I long to see the lights twinkling along the riva as the train passes Miramar. After all, Nora, it is the city which has sheltered us. I came back to it jaded and moneyless after my folly in Rome and now again after this absence (Letters II 249).

It might, however, be argued that such lyrical praise of the city was more the product of his missing Nora or, alternatively, that it was not Trieste's ultra-Italian heart that appealed to Joyce but its multicultural make-up as the principal port and emporium of "Old Auster and Hungrig" ( $F W 464.27-28)$, its quality of being, in Ippolito Nievo's words "un piccolo compendio dell' universe" (a small compendium of the universe). ${ }^{1}$ That said, Joyce does seem to allude to Trieste's role as an Italian storehouse of material for his writing in Finnegans Wake when he writes about "the cummulium of scents in an italian warehouse" ( $F W 498.31)$ and there is no doubt that his long and often difficult sojourn there, to which he alluded in Finnegans Wake in the

\footnotetext{
${ }^{1}$ Nievo quoted in Fulvio Tomizza, Alle Spalle di Trieste (Bologna: Bompiani, 2000), p.7.
} 
line "And trieste ah trieste ate I my liver" $(F W 301.16),{ }^{2}$ was also a fruitful and propitious occasion for his writing.

If Joyce is not shy about dismissing Italian cities, neither was he slow about dishing out often stereotypical judgements about the country and its inhabitants. One among many, which I cite because it employs the peculiar mix of admiration and condemnation that characterize most of Joyce's comments about "Illbelpaese" ( $F W$ 129.27), is to be found in Scribbledehobble (Buffalo notebook VI.A) written in 1922-23, the longest of the Joycean notebooks containing material for Finnegans Wake. Among its 3,500 notes, we find: "Italians build Europe and half America and Italy is a ruin". ${ }^{3}$ Earlier, in the Eumeus episode of Ulysses, more non-flattering Italian references can be found. In this episode, the icecream sellers (and in Ireland this was a trade almost exclusively plied by Italian immigrants) are heard "in heated altercation ... in their vivacious language" ( $U$ 16.310-311). In order to understand the violence which Joyce wishes to inscribe onto this dialogue, it is useful to recall his own Victorian prudery with regard to curses and oaths shouted aloud and in public.

- Puttana madonna, che ci dia i quattrini! Ho ragione? Culo rotto!

- Intendiamoci. Mezzo sovrano più ...

- Dice lui, pero

- Mezzo.

- Farabutto! Mortacci sui!

- Ma ascolta! Cinque la testa più ... (U 16.309-19)

What might have caused Joyce to place this piece of uniquely untranslated dialogue in Ulysses? While there are other instances of foreign languages appearing in the novel, this is among the most sustained, authentic and correct and yet a good deal of its power and meaning would clearly be lost on non-Italian readers, who would

\footnotetext{
${ }^{2}$ There is, of course, an echo of Paul Verlaine here. Joyce's Triestine friend, Dario de Tuoni, later recalled that Joyce often recited Verlaine: "During our night walks ... he would exclaim in a mysterious and saddened tone: ' $O$ triste, trieste était mon ame' A cause, a cause d'une femme." Dario De Tuoni, Ricordo di Joyce a Trieste /A Recollection of Joyce in Trieste, eds. Renzo S. Crivelli and John McCourt (Trieste: MGS Press, 2002), p. 128.

${ }^{3}$ Thomas E. Connolly, ed., James Joyce's Scribbledehobble: The Ur-Workbook for Finnegans Wake (Evanston, Northwestern University Press, 1961), pp. 101-102.
} 
probably have to work hard to understand the vulgar "puttana madonna" (whore mother), to figure out that "mortacci sui" was a curse against someone else's dead and to realize that the argument was to do with money given words like "quattrini" and "mezzo sovrano" (half a sovereign). The term "farabutto" would be likely to be lost on non-Italians. Dating from the sixteenth century, it was common in southern Italy, but probably came from the German "freibeuter" meaning thief. ${ }^{4}$ Might there not be an echo in this episode of Joyce's Roman sojourn, an echo of an unpleasant memory of being robbed of his pay on his last night in Rome? Joyce certainly was not one to easily forgive a wrong suffered and perhaps in these lines he was exacting a revenge of sorts on the Romans for misadventures suffered among them by putting some of the most awful blasphemies of which they were capable into his fiction. What is certain is that he returned to "docile Trieste" (GJ 10) from Rome the day after being robbed and was full of anger and resentment that would not leave him easily. Stanislaus, in his Triestine Book of Days, leaves a moving description of the family's arrival on "the Italian train" on the evening of 7 March 1907:

They looked almost as thin and poverty stricken as Italian emigrants when I saw them coming down the platform in the stream of passengers. Jim was thinner than when he left; pale and smiling a little as if he had been drinking [...] and peering short sightedly about for me and for his luggage. He wore a little grey soft hat, and a mangy shapeless cape-coat which he bought off Scholz for five crowns before he left Trieste hung anyway from his shoulders. He was unshaven. Nora, in a trollopish hat and looking thinner and more bedraggled than ever, had Georgie in her arms (Book of Days, 7 March 1907). ${ }^{5}$

The next night, Joyce told Stannie about the robbery, explaining that he had been drunk in a caffè and found himself talking to "two respectably dressed bowsies" having just been paid for lessons. When the time came to go home,

\footnotetext{
${ }^{4}$ See Mario Doria, Grande Dizionario del Dialetto Triestino (Trieste: Edizioni Trieste Oggi, 1991), p. 225.

${ }^{5}$ A photocopy made by Richard Ellmann of Stanislaus Joyce's Triestine Book of Days is kept at the McFarlin Library at the University of Tulsa.
} 
the bowsies asked Jim for his card, and Jim took out his pocket-book to give them one, and while he was looking for one in the dark, the bowsies snatched the pocket-book and ran. Jim ran after them but, being very drunk, he stumbled and fell heavily and was stunned. Someone passing, who knew him, picked him up and brought him back to the caffe. Men were sent out to look for the thieves but Jim kept saying that he wanted to go home to his Nora and his little Georgie. I recognize the stage of drunkeness. He was eventually carried home. (Book of Days, 7 March 1907)

The next day, after attempting unsccessfully to get help from the police, Joyce went back to the Caffè where the owner pretended not to recognize him. He "said he remembered nothing at all of the two men to whom Jim had been speaking. They were probably friends of his, being Romans. Jim told the Banker that he wished to leave Rome at once" (Book of Days, 7 March 1907).

And leave Rome he did, the next morning, never to forget what had happened to him. His old employer in Trieste, Almidano Artifoni, whose name would of course reappear in A Portrait and Ulysses, rubbed salt into the wounds by firmly refusing to give Joyce yet another loan. Joyce reacted badly to this refusal, telling Stannie to tell Artifoni to "go to hell". "These cursed Italians!", he concluded, "Damn the thing they think about money" (Book of Days, 7 March 1907). Elsewhere, Joyce comments with regard to Artifoni and the director of the Berlitz, Giuseppe Bertelli, "when Italians are talking to you about money you might as well go out and take a walk. They'd prove black was white" (Book of Days, 14 May 1907). Rich, this, coming from Joyce.

To return for a moment to Eumeus, where, in marked contrast to the blasphemies of the icecream sellers, we find Bloom talking admiringly about the Italian language to a rather bored Stephen who contradicts him:

- A beautiful language. I mean for singing purposes. Why do you not write your poetry in that language? Bella Poetria! It is so melodious and full. Belladonna. Voglio.

Stephen, who was trying his dead best to yawn if he could, suffering from lassitude generally, replied:

- To fill the ear of a cow elephant. They were haggling over money. (U 16. 345-348) 
Bloom's stumbling Italian ("poetria" instead of "poesia", "belladonna", written as one word rather than two and, as a result, suggesting a type of poison rather than a beautiful woman) and Stephen's biting reply, contribute to Joyce's demolition of the clichéd idea of Italian as a musical, poetical language, the language of love, although the cliché will be played out again later in the book. Tenors most commonly sing Italian operas and tenors "get women by the score". In this key, Bloom will be cast in Circe in the role of a romantic lover with traits of "Mario the Tenor" (U 15.2620-30). But Joyce evokes these commonplaces to move beyond them so he can feel free to indulge his fascination with the Italian language, with its rhythms and polysyllables, its flexibility and its innumerable dialectical variations. In particular he will enjoy the fun that he can derive from putting strange combinations of Italian words and syllables together, something which is just not possible in English, combinations such as "patatapapaveri" $(F W \quad 172.22)$ and "Occitantitempoli" ( $F W$ 230.16) which sound, to an English speaker, as Italian should sound, but do not really mean anything - even if the first translates as "potatopoppy" and sounds a little bit like a variation on Triestine words such as "patatin-patatun" (in an instant) or pataton (beautiful girl) and the second seems to include the Triestine word "Ocio" (look out) and the Italian city of Empoli.

Joyce, as I have already mentioned, started studying Italian in Belvedere and continued at University College Dublin with Padre Ghezzi, a Bergamasco with whom he read Dante and D'Annunzio. In Stephen Hero, Joyce described how the "Italian lessons often extended beyond the hour and much less grammar and literature was discussed than philosophy" (SH 169). Joyce's real Italian language school was, however, Trieste, the cosmopolitan port city he came to call "la mia seconda patria" (my second country). There he learned a less scholastic version of Italian, initially through lessons with his friend and colleague, Tuscan-born Alessandro Francini Bruni, who later remembered that Joyce's Italian, a hybrid mix of everyday language, Dantesque locution, and phrases from the opera librettos and d'Annunzio, was clumsy, a dead language ${ }^{6}$. Joyce's Italian, however, was certainly a lot more accomplished than that of so many of the emigrants around him in Trieste, who, like him, had adopted Trieste as

\footnotetext{
${ }^{6}$ Alessandro Francini Bruni, Joyce intimo spogliato in piazza (Trieste: La Editoria Libraria, 1922), p. 11.
} 
their home having travelled there from Slav countries, from Austria, Greece, Hungary and from all "all the ends of Europe" (U 18.1589).

That said, Joyce came to realize fairly early that he would need to study hard to learn the language properly. He learned the hard way: in an optimistic early letter written in December 1904 from Pola, he announced that he was working on a translation into Italian of "Mildred Lawson", the opening story of Moore's Celibates, for an important Florentine publisher (Letters II 74). The manuscript containing this translation shows clearly that Joyce was not capable yet of a translation as difficult as this (translating out of one's mother tongue, in any case, is always a treacherous occupation). So Joyce's Italian version is full of spelling mistakes, grammatical errors, misunderstood sentences, overly literal interpretations which give it an unnatural feel and make for painful reading. Take this as an example:

I don't know anything about Comte - I wish I did; it is so dreadful to be ignorant. I never felt my ignorance before, but that little woman does make me feel it $[\ldots]$

Joyce's Italian reads:

Non so niente di Comte - magari si. è così annoioso ignorare queste cose. Non ho mai sentito la mia ignoranza fino adesso ma questa piccola donna mi fa sentirla [...] (JJA 1: 536)

Lots of serious mistakes, non-existent syntactical constructions, such as "magari si" when "magari" (I wish it were so) is never followed by anything. The final phrase "mi fa sentirla" is simply wrong and should be "me la fa sentire". Non-existent words and phrases that would never be used by a native speaker are also present. "Annoioso", for example, seems to be a cross between the Italian "noioso" (boring) and the English "annoying" with perhaps the influence of the Triestine verb "noiar" (to bore, to be bored) or the standard Italian "annoiare". These two "false friends" are often mixed up by English mother tongue speakers of Italian. What is interesting about this is to see Joyce, who would of course make his readers struggle in a language foreign to them in that endless union of languages that is Finnegans Wake, struggling for linguistic survival himself. He soon abandoned the translation and, with Francini Bruni's help, started the humble task of learning the language more adequately through imitation and 
practice and through an implementation of what he had written himself in his essay "The Study of Languages" in 1899:

the study of language must begin at the beginning and must advance slowly and carefully, over ascertained ground. ... Now the study of languages is based on a mathematical foundation, and sure of its footing, and in consequence both in style and syntax there is always present a carefulness, a carefulness bred of the first implantings of precision. $(O P C W 13)$

Side by side with a systematic attempt to become familiar with Italian classics and standard versions of the Italian language, Joyce was also curious about more popular language specimens. Proof of this is to be found in a notebook held at the National Library of Ireland. Among the many things we find in Italian in this notebook are nursery rhymes in Italian. One of them tells the story of San Nicolò di Bari. Joyce jotted down this rather macabre rhyme which was popular with children in Trieste. The version in the Joyce notebook is not an entirely correct transcription of the nursery rhyme that reads as follows:

San Nicolò di Bari

La festa dei scolari

I scolari non vuol fare festa

San Nicolo ne taglia la testa.

Loosely translated it reads: "Saint Nicholas of Bari, the schoolchildren's holiday, the schoolchildren do not want to have a holiday, Saint Nicholas cuts off their heads". Before each of the four lines Joyce writes a name, first "St. Nicholas", then "Sant Niklaus", then "Sant "Klaus" and finally "Santa Claus": in other words he traces the origins of Santa Claus trans-linguistically. Between the fourteenth and fifteenth centuries, San Nicolò di Bari, who later became patron of scholars along with Saint Catherine of Alexandria, began to be known as the patron saint of children and later came to be called Santa Claus. Here, in prototype is an example of Joyce's fascination with names and naming, with the narrational possibilities offered by names. As he pointed out in his essay "The Study of Languages", "in the history of words there is much that indicates the history of men" $(O P C W$ 15). All one needs to do is change a letter or two and the 
name changes nationality, changes location, changes time. A list of names can tell a story on its own, an important one sometimes, such as that of Santa Claus. Joyce's philological fascination with etymology and more specifically with onomastics - that is, with names and their origins, which we get a glance of here in this 1904 note-taking would later become a fundamental element in Ulysses and even more so in Finnegans Wake.

Another example of Joyce's method in gathering and then making use of Italian material can be found in the anti-clerical verse he wrote down in the same notebook about Don Zanetti "muso di porco" which literally translates as "pig face". In Triestine, "porco" denotes a dirty, sweaty, dishonest and generally deplorable individual (it often also has sexual connotations). These two examples reveal an Italian variant of his attraction not only for "high" culture but also for the popular culture of the streets and bars of Pola, Trieste, or Rome.

In the "polygluttural" ( $F W$ 117.13) city of Trieste, the use of Triestino was more or less obligatory. This provided occasions for Joyce to become familiar with the rather "low" dialectical forms adopted in everyday conversation. Some of the exchanges in Triestino were recorded by Stanislaus in his diary, such as the following:

We had opportunities, too, of experiencing the politeness of

Triestines. We knocked at the door of a quarter. Five minutes afterwards the door is opened by a fat, frowsy young woman, without stays or skirt, bent with wobbling, shapeless breasts and disheveled hair, who surveys us from top to toe and asks rudely:

'Cosa la vuoi?'

'C'è una camera di affittarsi qui?'

'Per chi xe?'

'Per me e mia moglie. Il portinaio mi a detto che -'

'Le ga fioi?'

'Si, uno. Posso vedere la stanza?'

'Ah, non xe una camera' (Book of Days, 14 August 1907).

Stanislaus, whose Italian was never as accomplished as that of his brother, makes a less than perfect attempt to transcribe the Triestino he hears. The "Cosa la vuoi?" meaning "What do you want?" should be "Cossa la vol?". The "vuoi" is standard second-person singular Italian. The second line "C'è una camera di affittarsi qui?" is correct standard Italian meaning "Is there a room to let here?". "Per chi xe?" 
("Who is it for?") is correct Triestine. "Per me e mia moglie. Il portinaio mi a detto che -" ("For me and my wife. The porter told me that...") is again standard Italian although the "a" should be "ha". "Le ga fioi?", or "Have you got kids?" is pure Triestine, at its most direct: "fioi" the plural form of "fio" means "child" from the Latin "filius". A common Triestine expression was "Fioi e colombi smerda la casa" meaning "children and pigeons dirty the house", a motto, this, which the landlady in question would surely have endorsed.

If Triestino was the language of the streets, the public language of interpersonal exchange for Joyce, Italian seems to have dominated at home in conversation involving Giorgio and Lucia. In a letter to Stanislaus, Joyce told his brother how Giorgio, aged just one, had added the following words to his vocabulary. "O Gesu mio" and "Brutto, brutto, brutto" and that he greeted the arrival of each new course at the restaurant with the words "Ettero, ettero" [which is a meaningless word, a child's attempt to pronounce "eccolo" meaning "here it is"] (Letters II 152). Joyce would return to the word "eccolo" in Finnegans Wake, in the passage describing early morning copulation: "Echolo choree coroh choree chorico!" ( $F W$ 585.3-5) This time "Echolo" - eccolo - suggests "Here it comes" and is followed by a mixture of the Italian "coccodè" and "chicchirichì" (which are onomatopoeic expressions meaning "cackle" and "cock-a-doodledo"). ${ }^{7}$

The use of Italian in a household where both parents were mothertongue English speakers was strange and was probably damaging to the children, who were thus deprived of the certainty of a mother tongue. But it wasn't so strange in the Trieste of that time. Italian or perhaps better Triestino, was the lingua franca also of the immigrants who were settling in the city and who knew, that in order to get on, they had to blend in linguistically. Many years later, in a letter to Helen Joyce, Joyce explained why he still continued to write to Giorgio in Italian. "Not", says Joyce, "to hide anything but because when Giorgio was introduced to me thirty years ago by dott. Gilberto Sinigallia; I said to him 'Toh! Giorgio!' to which he (Giorgio) replied 'Baaaa Booooo'. Da allora la nostra conversazione ha sempre

\footnotetext{
${ }^{7}$ See Margherita Maleti, "Rejoyce in Peace: A Study of Finnegans Wake III.4." mediAzioni: online journal of Interdisciplinary Studies in Languages and Cultures 1 (2005), http://www.mediazionionline.it/english/articoli/maleti_english_xxx.htm.
} 
continuato in quella lingua." ('Since then our conversation has always continued in that language'; Letters 1 380-381.)

Evidence survives of Joyce's attempts to assimilate higher Italian literature and culture. A notebook entitled "Italiano" (now in Cornell) was entirely used by Joyce for grammar exercises and to copy passages in Italian (examples of good Italian writing style). In applying himself in this way Joyce was perhaps mindful of his own claim that "the names we meet in the literature of our language ... are landmarks in the transition of a language ... standards for imitation and reference, and are valuable because their use of the language was also based on their study of it" $(O P C W 15)$. Consequently, Joyce laboriously copied out passages from various Italian authors including Luigi Barzini (La metà del mondo), Raffaello Fornaciari (Letteratura italiana) Gabriele D'Annunzio (Il trionfo della Morte), Libero Merlino (I principi dell'anarchia), Torquato Tasso (L'Aminta) Giacomo Leopardi (Pensieri), A.C. Firmani (Tacito e le sue opere), Paolo Giacometti (La morte civile), Brunetti Latini (Il libro delle bestie). ${ }^{8}$ This notebook can probably be dated back to the period before Joyce began his first real literary translations into Italian along with Nicolò Vidacovich. Together they translated Synge's Riders to the Sea in 1909, and their joint version is extremely successful. By then, Joyce's Italian was excellent and he was able to get regular work translating commercial letters to and from Italian for local businessmen and to publish his articles in Il Piccolo della Sera in Trieste without having them revised by anyone. Dario De Tuoni, one of the few Triestine friends of Joyce (after 1910) who left a reliable account of the author, gave testimony to his proficiency - although he did maintain that Joyce always spoke Italian with a slight accent: "Only once did I hear him make a mistake: in the expression "bianco mano" [rather than "bianca" as "mano" - hand - is feminine] which just slipped out. An error due to a momentary distraction and justified by the fact that nouns ending in $o$ in Italian are usually masculine with few exceptions, one of them being "mano". It was one of those

\footnotetext{
${ }^{8}$ For a detailed discussion of this notebook, see Serenella Zanotti, "Per un ritratto dell'artista italianato: note sull'italiano di James Joyce con edizione di un testo", Studi Linguistici Italiani 25, no. 1 (1999): 16-63. See also her "An Italianate Irishman: Joyce and the Languages of Trieste", in "Joyce and Trieste", ed. John McCourt, special issue, JJQ 38, no. 3-4 (Spring-Summer 2001): 431-452.
} 
oversights which are easy to commit when one is speaking quickly in a foreign language."

In irredentist Trieste, Joyce deepened and broadened his knowledge of Italian literature, reading Dante, Carducci, Verga, Pascoli, Leopardi, Fogazzaro, Matilda Serao. D'Annunzio and Martinetti were among the many illustrious literati to lecture regularly in the city, and Joyce of course came to know the local writers well, such as Italo Svevo, Silvio Benco, Dario De Tuoni, as well as the local futurists and the vociani Umberto Saba, Scipio Slataper, and Angelo Vivante. D'Annunzio had a particularly large following. Joyce had of course already read him in Dublin and been struck by Il Fuoco, which he praised as the "highest achievement of the novel to date", ${ }^{10}$ a huge step forward with respect to Madame Bovary. He read Le Vergini delle Rocce and the plays La Gioconda, La Gloria and Sogno d'un tramonto d'autunno. He deepened and extended his interest in Trieste, where his student, a certain Miss Luzzatto, ${ }^{11}$ lent him other books by D'Annunzio including L'Innocente, Il Trionfo della Morte, La Città Morta. Soon, however, Joyce's enthusiasm for D'Annunzio waned. By 1907 he was calling him a "mere charlatan". He had even less time for Carducci, whose "vain-glorious bombast" he disliked heartily, while Pascoli was dismissed as a mere "word monger", incapable of putting his soul into what he wrote. Despite the severity of these judgements, we'd perhaps do well not to take them too seriously. Often in Joyce, strident criticism is the independent, autonomous artist's cover for real interest - his comments on the Irish Literary Revival being a good case in point. Despite the comments about D'Annunzio, there is no doubt that the Joycean sense of the epiphany at least in part is derived from D'Annunzio's model. Not for nothing did Melchiori define the relationship between young Joyce and d'Annunzio as a sort of discipleship. ${ }^{12}$

The fact is that Joyce's interest in Italian literature was deep and constant as was his interest in the Italian language, a language which,

\footnotetext{
${ }^{9}$ De Tuoni, Ricordo di Joyce, p. 128.

${ }^{10}$ Stanislaus Joyce, My Brother's Keeper, ed. Richard Ellmann (London: Faber and Faber, 1958), p. 154.

11 "Miss Luzzatto" is one of the few Triestini named in the Scribbledehobble notes for Penelope, p. 169 (with "Miss Popper" who is Amalia Popper, the probable inspiration of Giacomo Joyce).

${ }^{12}$ Giorgio Melchiori, Joyce's Feast of Language: Seven Essays and Ten Notes, Joyce Studies in Italy 4, ed. Franca Ruggieri (Roma: Bulzoni, 1995), p. 101.
} 
especially in Finnegans Wake, plays an important role in Joyce's attempt to free himself from "the most ingenious torture" of having to write in English. Italian and Italian culture in the broadest of senses were important sources. Stephen's comments in Stephen Hero about Skeat can also be applied to Joyce's own feelings for the Italian language (and of course for language in general):

It was not only in Skeat that he found words for his treasure-house, he found them also at haphazard in the shops, on the advertisments, in the mouths of the plodding public. He kept repeating them to himself till they lost all instantaneous meaning and became wonderful vocables.

Joyce, like Stephen, is horrified with people who are "strangely ignorant of the value of the words they used so glibly" (SH 29). Giorgio Melchiori convincingly argues that this

is an uncannily lucid anticipation of Joyce's relationship to language up to and mainly in the last of his works, Finnegans Wake. Words, the words literally picked up in the street, we are told, in order to be rescued from the hell of hells, which is the hell of the Obvious, must lose "all instantaneous meaning", and then they become "wonderful vocables". The Eucharistic act consists in investing with a meaning beyond meaning the meaningless words and phrases pieced together with deliberate and unflagging seriousness in the house of silence. This is exactly what happens in the writing of Finnegans Wake. The language of Finnegans Wake is a constant epiphanisation of the current, familiar, obvious everyday language, by a process of translation that intensifies to the utmost its semantic values, so that the banal becomes memorable, the common word becomes a wonderful vocable. $^{13}$

The common word (which is never common in Joyce) becomes the place of almost unlimited discovery but also a very serious game. By detaching words from one particular language or world, Joyce, in a sense, uproots them or sets them free and is thus able to enjoy them as pure sounds and as containers of almost unlimited meaning. One of our tasks as readers is to at least temporarily reunite them to their sources (books, newspapers, languages), to place them somehow in their pluridialectal "idioglossary" $(F W 423.9)$ in order to find meaning

\footnotetext{
${ }^{13}$ Ibid.
} 
in them and assemble coherence among them. We do this when faced with what Katie Wales has described as a "universalised HibernoEnglish" $" 14$ in Finnegans Wake, knowing that Joyce chose to at least partially exile himself from his mother tongue, to distance himself from English as it is commonly used and to create a language based on English but which keeps renewing, which resists being traced back to a single source, which is deviously complex in its multiplicative strategies of creating meaning. As such of course it makes huge demands on the reader whose reading, by necessity, becomes an act of translation. In the best of cases the reader is translator but often he or she is left to struggle to make sense of an almost endless cacophony of echoes being heard in this game-like language or these languages whose rules always resist clear definition, whose syntax or "sintalks" ( $F W$ 269.3) is, like Hamlet's time, "out of joint", one of constant deviation and non conclusion.

Among the echoing languages, Italian has an important role to play. Finnegans Wake is a rich source of various types of Italian. We find, for example, italianized English phrases like "bucket of water" which becomes "boccat of vuotar" (where "boccat" suggests "bocca" (mouth) and "vuotar" suggests "vuota" (empty); anglicized Italian in words like "fracassing" ( $F W$ 206.01) (making a terrible noise, great confusion) merendally ( $F W 406.01)$ where "merenda" means "snack" or "breakfast".

Rosa Maria Bosinelli has described these two examples as "amusing morphological manipulations typical of schoolboys first learning English"; 15 perhaps closer to home, they echo the efforts of Giorgio and Lucia Joyce to speak in English. Another interesting portmanteau word is "Piscisvendolor" $(F W$ 408.36) from "pescivendola" (a seller of fish) with the addition of the word "dolore" (pain), suggesting a seller of pain. In Scribbledehobble, Italian is also prominent. We find there, for example, a list of common and seemingly random Italian words Joyce hoped to put to use later to build wordplays, such as "analfabeta" (illiterate) "ricatto" (blackmail), and common phrases or sayings such as "mi fa venir la pelle d'oca" (15) (literally "it gives me goosebumps" or more commonly "it gives

\footnotetext{
14 Katie Wales, The Language of James Joyce (Basingstoke and London: Macmillan, 1992), p. 33.

${ }^{15}$ Rosa Maria Bollettieri Bosinelli, "The Relevance of Italian in Finnegans Wake with Reference to I.1-8", A Wake Newslitter 13 (April 1976): 19-32.
} 
me the shivers"). There is also the common Triestine question "cosa la mi corti de bel" (112) - which should read "cosa la mi conti de bel" the error is probably one of transcription and which translates a little oddly into English as "What good news have you got for me?" ("conti" is the second person singular of the Triestine verb "contar", while the standard Italian is "raccontare". Going back to Finnegans Wake we find invented altered Italian exclamations such as "Alvemmarea" (a cross between "Avemaria" and "marea" meaning "tide" but also suggesting "trouble" in a more colloquial usage, $F W$ 244.14) or "Diavoloh!" ( $F W$ 466.27) - here a "h" is simply added to the Italian word for devil; the common invocation "Corpo di Bacco" becomes a long series of near but rather senseless synonyms such as "Corpo di Barraggio!" ( $F W$ 48.1) or later "gorpodipacco" (FW 69.36), "Culpo de Dido!" ( $F W$ 357.15) and "Colpa di Becco" ( $F W$ 412.29). We also find mangled titles of Italian arias such as Don Bassilio's "La calunnia é un venticello" (Calumny is a little breeze) from Rossini's Il Barbiere di Siviglia, which becomes "Chelli Michele's La Calumnia e un Vermicelli" ( $F W$ 199.29-30), with the thin, spaghetti-like pasta taking the place of the breeze. The habit of punning, already well established in Ulysses where we find, among many others, il "Commendatore Bacibaci Beninobenone", is also applied to Italian names and surnames. Among those that jump out: "Miss Fragranzia in Flagrante" (Scribbledehobble 139) "Signorina Cuticura" ( $F W$ 164.30), "Betty Bellezza" ( $F W$ 211.14). "Miss Corrie Corriendo" ((FW 220.19), translatable as "Miss run runnying (sic)" "Bianca Mutantini" ( $F W$ 238.24) which un-problematically translates as "White Knickers" (although Bianca is of course also a popular woman's name in Italy). Their eminences "Cardinal Lindundarri, Cardinal Carchingarri and Cardinal Loriotuli and Cardinal Occidentaccia" ( $F W$ 180.13-15) again sound like Italian names but are not actual names at all, just sounds, enjoyed by Joyce for their Italianate polysylabblic qualities (though Joyce clearly enjoys playing, in the last example on a Cardinal and an astrological cardinal point).

Joyce is also taken by the diminutives offered by Italian. We need think only of 1909 letter to Nora from Dublin which concludes: "God in heaven, I shall be happy there! I figlioli, il fuoco, una buona mangiata, un caffè nero, un Brasil, il Piccolo della Sera, e Nora, Nora mia, Norina, Noretta, Norella, Noruccia ecc ecc ... (SL 191). What Joyce is forced to call "A Little Cloud" in English can, with the 
benefit of Italian and of Nicolò Tommaseo's Dizionario dei Sinonimi, a copy of which Joyce owned, become the infinitely more poetic "Una nuvoletta" (although practically every Italian edition of Dubliners has chosen to call the story "Una piccola nube" or "Una piccola nuvola". The "nuvoletta" is a derivative of "nuvola", a word which in the Dizionario morphs into a rich variety of linguistic options, into a whole world of words, mostly deriving from the latin adjective "nūbila" (cloudy): "núvola, nuvolo, núgolo, nugolone, nuvoletta, nube, nuvolágha, nuvolato, nuvoloni", and then, from the latin "nimbus" (storm cloud), we find "némbo, nimbo" with an infinity of definitions and citations from Italian literature such as the one from Dante "la fiamma sola, sì come nuvoletta, in su"16 (the single flame, yes, upwards, like a little cloud). These annotations might later become useful to Joyce and not for nothing do we find this in the beautiful passage in Finnegans Wake:

Nuvoletta in her lightdress, spunn of sisteen shimmers, was looking down on them, [...] Nuvoletta listened as she reflected herself, though the heavenly one with his constellatria and his emanations stood between [...] Not even her feignt reflection, Nuvoluccia, could they toke their gnoses off for their mind [...] Then Nuoletta reflected for the last time in her little long life and she made up all her myriads of drifting minds in one. She cancelled all her engauzements. She climbed over the bannistars; she gave a childy cloudy cry: Nuée! Nuée! (FW 157.8-25; 159.6-9)

Echoes of Triestine dialect are also to be heard in Finnegans Wake often anglicized in words such as "cagacity" ( $F W$ 108.18), from the triestino "cagar" (Italian: defecare, English: defecate) and the English "sagacity". ${ }^{17}$ Sometimes the spellings are completely original but perfectly recreate the pronunciation - the inability of Triestines to say their "e" which becomes a hard "a" as in "escapa sansa pagar" ( $F W$ 464.11) which would read in Triestine "e scapa senza pagar" (and runs away without paying). Triestine words are inserted in phrases essentially written in standard English. We find the word

\footnotetext{
${ }^{16}$ Nicolò Tommaseo, Dizionario dei Sinonimi (Milano: Francesco Vallardi, 1908), p. 558 .

${ }^{17}$ Some of these are listed in Serenella Zanotti, "The Image of the Italian Language in Finnegans Wake", in Prospero, Rivista di culture anglo-germaniche 7 (2000): 145158.
} 
"Mona" (referring to the female sexual organ and a common term of abuse) used to transform an apparently innocuous and even romantic English phrase into a heavily sexualized syntagm: "Was Mona, my own love, no bigger than she should be, making up to you in her bestbehaved manor when you made your breastlaw and made her, tell me?" ( $F W$ 464.32-34) This example is fairly typical of how Joyce used Italian curses, oaths and vulgar expressions. Very often, in Finnegans Wake, the only "offending article" is the Italian one. Similarly we find the following example in Notebook VI.B.5: "K wonders why cazzo given" (V1.B.5.009). The "cazzo" is a vulgar expression for the male sexual organ.

From these rather low depths Joyce reached effortlessly upwards into Italian literature and Dante. His works are packed with references to Dante Alighieri or "Denti Alligator" as he is called in Finnegans Wake. Joyce read La Divina Commedia for the first time in his final school years at Belvedere College, and again with Padre Carlo Ghezzi, at University College Dublin. More than once he claimed that "Italian literature begins and ends with Dante", "I love Dante almost as much as the Bible. He is my spiritual food, the rest is ballast" (JJII 218).

Nothing new here. But what is new is that among the new materials at the National Library of Ireland we now find 28 pages of annotations to Dante. These "notazioni", to use the word Joyce himself employs on the opening page of his notebook, are fascinating. Each page corresponds to a canto number and contains citations, comments, sometimes translations of difficult sentences. 25 of the 34 Cantos of the inferno are covered. ${ }^{18}$ This notebook is a Dublin one. Once he got to Trieste, Joyce returned to Dante having bought a copy of Vita Nuova and his fascination with the Italian author never waned. Dante offered Joyce an unprecedented model of linguistic polysemy and plurality, one to emulate, learn and borrow from as well as to parody and challenge. ${ }^{19}$ Louis Gillet's words suggest parallels in terms of multiple readings which are possible in both the Divina Commedia and Finnegans Wake: "The text [Work in Progress] has to be read like Dante's, according to several superimposed meanings. There is a

\footnotetext{
${ }^{18}$ For further information see Dirk Van Hulle, Joyce and Beckett, Discovering Dante (Dublin: National Library of Ireland, 2004).

${ }^{19}$ See Lucia Boldrini, Joyce, Dante, and Poetics of Literary Relations: Language and Meaning in Finnegans Wake (Cambridge: Cambridge University Press, 2001), p.6.
} 
literal meaning, an allegorical meaning, and perhaps several others almost as many as the skins of an onion." 20 Furthermore, Dante's use of language is a model for Joyce as is his insistent use of the vernacular; Joyce appreciated Beckett's description of Dante's "synthetic language that would at least possess more than a circumscribed local interest" ${ }^{\prime 21}$ and presumably saw a parallel with his own literary language.

The language of Finnegans Wake is also synthetic. The word, in Joyce's hands, takes on a life of its own, resists classifications and its ethnology incarnates the idea of hybridization, contamination, migration, stratification, assimilation. This is part of the greatness of later Joyce, a man writing between the shadows of two world wars, under the threat of exasperated nationalisms, and the rampant Fascism and Nazism that were about to tear Europe apart. The Italian language became for him an important element in his mission to explode the notion that English or any other language for that matter could be used as means to classify a race. Joyce came to refuse the very word race, the idea of purity summed up the blend of Irish-German nationalism in Finnegans Wake as the "eirest race, the ourest nation, the airest place that erestationed" ( $F W$ 514.36-515.1). Writing against notions of pure Aryan and pure Irish here, Joyce gave voice to the "confusioning of human races" ( $F W$ 35.5) and in doing so gave voice to a union of languages and to the Europe he saw from afar, longed for from Dublin and discovered at first hand in the multicultural city of Trieste, and in Zurich, city of refugees and later in Paris. In this way, the earlier cited example of the steps from San Nicolò to Santa Claus can be read as an early Joycean prototype for this vastly ambitious project. The addition of a letter or two can change race and meaning, can cause something to become something else. The knowledge of this lies at the heart of Joyce's demolition of the exasperated nationalism of the countries at war and his attempt to give voice to Europe itself which caused him, for once to eat those words of his written from Pola in 1904: "I hate this Catholic country with its hundred races and its thousand languages" (Letters I 57).

This effect of Joyce's "confusioning" is to unite all Joyce readers as foreigners (or Italians) before the provisionally English text of

${ }^{20}$ Louis Gillet, Claybook for James Joyce (London and New York: AbelardSchuman, 1958), p. 58.

${ }^{21}$ Quoted in Van Hulle, Joyce \& Beckett, p. 58. 
Finnegans Wake and yet also to empower each and everyone to bring his own language and experience to bear on the limitless linguistical union that is his last book. 